J. Perinat. Med.

3 (1975) 154

\section{Dyspnea in pregnancy}

\author{
Volker Lehmann \\ Dept. of Gynecology, University of Würzburg \\ (Chairman: Prof. Dr. K. H. Wulf)
}

Received January 10, 1974. Accepted March 11, 1975.
Comroe et al. [1] define dyspnea in their book "The Lung" as a subjective symptom only sensed by the patient, the severity of which can only be gauged by the patient, as is true for other sensations. Dyspnea at rest occurs in $20 \%$ of pregnant women already in the 12th week of pregnancy. During a slight physical load $60 \%$ of pregnant women report that they are short of breath [2]. No satisfactory explanation for this symptom has, as yet, been found.

Pulmonary functions were examined in 23 women during pregnancy and after delivery. Eight of these reported shortness of breath at rest already from the 10th to 12th week of gestation. The values for their lung function tests were compared with those of 15 women not suffering from dyspnea.

\section{Material and methods}

Twenty three pregnant women aged 21 to 34 years were examined. The course of pregnancy was normal. All delivered spontaneously at the end of gestation. Pulmonary functions were examined in the 12th, 24th, 32nd and 36th weeks of pregnancy. The same subjects were re-examined 12 weeks after delivery in order to obtain control values. Eight patients spontaneously reported shortness of breath between the 10th and 12th week of pregnancy. Their pulmonary functions in the 12th week of gestation were compared with those of the remaining 15 women.

Lung volume, ventilation, respiratory mechanisms and diffusion capacity were examined

\section{Curriculum vitae}

Born in Kiel in 1938. Studied and graduated in Kiel, 1963. University of Kiel, Dpt. of Obstetrics and Gynecologv, for 3 years as intern. 1969: Intern and resident at the medical Faculty, Dpt. Obstetrices and Gynecology, Hannover.

1973 babilitation.

Since 1973 senior resident at the Dpt. of Obstetrics and Gynecologv, University Wurrburg.

Research into acid base metabolism in mother and fetus at birth. Changes in oxygen affinity of fetal blood, energy turnover and bemodynamics at birth and pulmonary function during pregnancy.

in all 23 women. The cause of dyspnea in the first trimester was sought and hence the following parameters were of interest: oxygen consumption, minute volume, compliance, respiratory work against viscous resistance, and diffusion capacity.

These techniques, as used here, are routine in any larger laboratory for pulmonary functions [2]. Hence only the principle of the method is given. Lung volume and ventilation were determined with a closed system of a spirometer ("Pulmotest" GODART). This apparatus has two complete systems with spirometers, absorbers and the change in volume of both is recorded on a common kymograph. The left system is filled with a helium air mixture, the right one with oxygen. The amount of oxygen consumed by the subject is automatically replaced via an electromagnetically controlled. valve and oxygen consumption is thus read from the change in volume of the gas supply bottles. 
An esophageal baloon technique was used to determine the volume-pressure coefficient (compliance). Respiratory work against a viscous resistance was calculated by planimetry of the recorded respiratory loop.

Diffusion capacity for $\mathrm{CO}$ was determined by the method of KROGH as modified by FORSTER et al. [4]. The amount of $\mathrm{CO}$ that diffuses through the alveolar wall into the blood per $\mathrm{mg} \mathrm{Hg}$ pressure difference while the breath is held, is determined.

Means, standard errors and standard deviations were calculated. The significance of differences was tested using the t-test for two independent variables and for pair differences.

\section{Results}

Individual values, means and standard deviations are shown in Tabs. I to $\mathrm{V}$.

a) Minute volume: In women, not complaining of dyspnea early in pregnancy, a MV of 7,9 1/min was found when they were not pregnant. In the 12th week of pregnancy this had risen to $8.31 / \mathrm{min}(2 \mathrm{p}<0.05)$. In dyspneic women the $\mathrm{MV}$ rose from $8.4 \mathrm{l} / \mathrm{min}$ outside of pregnancy to $10.1 \mathrm{l} / \mathrm{min}$ in the 12 th week $(2 \mathrm{p}<0.01)$ (Tab. I).

Tab. I. Minute volumes in 15 women without dyspnea and 8 women with dyspnea determined outside of and in the 12th week of pregnancy $(1 / \mathrm{min})$.

\begin{tabular}{rrrr}
\multicolumn{2}{c}{ without dyspnea } & \multicolumn{2}{c}{ with dyspnea } \\
outside & 12th week & outside & 12th week \\
7.1 & 6.1 & 8.3 & 11.8 \\
5.3 & 7.6 & 8.0 & 8.7 \\
8.5 & 8.8 & 8.9 & 11.9 \\
7.3 & 7.7 & 7.6 & 8.6 \\
9.1 & 6.6 & 8.4 & 9.2 \\
6.7 & 8.6 & 7.9 & 9.3 \\
8.4 & 9.3 & 9.3 & 10.8 \\
9.7 & 8.8 & 9.3 & 10.6 \\
8.7 & 9.2 & $\overline{\mathbf{x}}=8.5$ & 10.1 \\
7.6 & 8.1 & $\mathrm{~S}=0.6$ & $\mathrm{~S}=$ \\
8.2 & 8.6 & & 1.3 \\
8.5 & 10.1 & & \\
7.8 & 9.0 & & \\
8.1 & 8.5 & &
\end{tabular}

Tab. II. Compliance in 14 women without dyspnea and 7 women with dyspnea outside of and in the 12 th week of pregnancy $\left(\mathrm{ml} / \mathrm{cmH}_{2} \mathrm{O}\right)$.

\begin{tabular}{|c|c|c|c|}
\hline \multicolumn{2}{|c|}{ without dyspnea } & \multicolumn{2}{|c|}{ with dyspnea } \\
\hline outside & 12th week & outside & 12th week \\
\hline 205 & 228 & 176 & 172 \\
\hline 130 & 135 & 124 & 122 \\
\hline 161 & 151 & 150 & 134 \\
\hline 132 & 138 & 143 & 167 \\
\hline 224 & 216 & 163 & 192 \\
\hline 138 & 123 & 132 & 122 \\
\hline 200 & 212 & 183 & 195 \\
\hline 268 & 262 & $\overline{\mathrm{x}}=\overline{153.0}$ & $\overline{\mathbf{x}}=\overline{157.7}$ \\
\hline 265 & 280 & $\begin{array}{l}x=150.0 \\
S=22.1\end{array}$ & $\hat{\mathrm{S}}=31.5$ \\
\hline 248 & 206 & $\mathrm{~s}=22.1$ & \\
\hline 218 & 230 & & \\
\hline 194 & 150 & & \\
\hline 172 & 184 & & \\
\hline 170 & 173 & & \\
\hline $\bar{x}=194.6$ & $\overline{\mathrm{x}}=192.0$ & & \\
\hline$S=46.7$ & $S=49.1$ & & \\
\hline
\end{tabular}


b) Tidal volume: This was $544 \mathrm{ml}$ air for normal women and $554 \mathrm{ml}$ for those with dyspnea and rose to 599 and 655 respectively in the 12 th week of pregnancy.

c) Respiratory rate: All women had 15 respirations per min within and outside pregnancy. d) Compliance: This was $194 \mathrm{ml} / \mathrm{cm} \mathrm{H}_{2} \mathrm{O}$ after delivery in normal women and 153 in the dyspneic group. In the 12th week of pregnancy the figures were 192 and 153 respectively (Tab. II). e) Viscous respiratory work: In the control group we calculated $2.6 \mathrm{gcm} / \mathrm{ml}$ both during and after the end of pregnancy. In the dyspneic group the values were 2.8 after delivery and $2.9 \mathrm{gcm} / \mathrm{ml}$ in the 12th week of pregnancy (Tab. III).

f) Diffusion capacity. In nonpregnant controls this was $26.4 \mathrm{ml} / \mathrm{min} / \mathrm{mmHg}$. No change was found in the 12th week of pregnancy $(26.1 \mathrm{ml})$. In dyspneic women, however, the

Tab. III. Viscous respiratory work in 14 women without dyspnea and 7 women with dyspnea outside of and in the 12th week of pregnancy $(\mathrm{gcm} / \mathrm{ml})$.

\begin{tabular}{rrrr}
\multicolumn{2}{c}{ without dyspnea } & \multicolumn{2}{c}{ with dyspnea } \\
outside & 12th week & outside & 12th week \\
3.5 & 3.3 & 2.3 & 2.1 \\
2.0 & 2.2 & 2.8 & 3.3 \\
2.3 & 1.7 & 3.0 & 3.5 \\
4.7 & 4.9 & 2.1 & 2.3 \\
4.2 & 4.1 & 3.6 & 3.8 \\
2.9 & 3.5 & 4.8 & 5.0 \\
1.0 & 0.5 & 1.0 & 0.8 \\
3.0 & 2.8 & $=2.8$ & $\overline{\mathrm{x}}=2.9$ \\
2.6 & 2.1 & $\mathrm{~S}=0.7$ \\
2.2 & 2.5 & $\mathrm{~S}=0.9$ & \\
1.9 & 1.6 & & \\
2.3 & 2.0 & & \\
2.0 & 2.2 & & \\
3.0 & 3.0 & &
\end{tabular}

Tab. IV. Diffusion capacity in 15 women without dyspnea and 8 women with dyspnea outside of and in the 12th week of pregnancy $(\mathrm{ml} / \mathrm{min} / \mathrm{mmHg}$ ).

\begin{tabular}{|c|c|c|c|}
\hline \multicolumn{2}{|c|}{ without dyspnea } & \multicolumn{2}{|c|}{ with dyspnea } \\
\hline outside & 12th week & outside & 12th week \\
\hline 27.3 & 28.6 & 28.4 & 27.9 \\
\hline 23.5 & 22.5 & 27.6 & 26.1 \\
\hline 22.4 & 23.5 & 22.4 & 20.0 \\
\hline 23.3 & 23.3 & 25.5 & 22.6 \\
\hline 27.4 & 26.6 & 28.5 & 21.0 \\
\hline 23.2 & 23.1 & 27.8 & 27.1 \\
\hline 28.7 & 26.6 & 27.0 & 26.8 \\
\hline 27.4 & 27.0 & 26.4 & 25.3 \\
\hline 26.8 & 26.0 & $\bar{x}=26.7$ & $\bar{x} \doteq \overline{24.6}$ \\
\hline 21.2 & 21.2 & $S=2.0$ & $\mathrm{~S}=3.0$ \\
\hline 30.8 & 32.1 & & \\
\hline 33.5 & 33.3 & & $\ldots$ \\
\hline 26.8 & 26.0 & & $\cdots$ \\
\hline 24.7 & 24.0 & & \\
\hline 28.9 & 28.1 & & \\
\hline$\overline{\mathrm{x}}=26.4$ & $\bar{x}=26.1$ & & \\
\hline$S=3.4$ & $\mathrm{~S}=3.4$ & & \\
\hline
\end{tabular}


'Tab. V. Oxygen uptake in 15 women without dyspnea and in 8 women with dyspnea determined outside of and in the 12 th weck of pregnancy $(\mathrm{ml} / \mathrm{min})$.

\begin{tabular}{|c|c|c|c|}
\hline \multicolumn{2}{|c|}{ without dyspnea } & \multicolumn{2}{|c|}{ with dyspnea } \\
\hline outside & 12 th wcek & outside & 12th week \\
\hline 218 & 217 & 186 & 191 \\
\hline 188 & 200 & 223 & 233 \\
\hline 235 & 245 & 187 & 216 \\
\hline 201 & 220 & 203 & 204 \\
\hline 186 & 227 & 231 & 226 \\
\hline 204 & 257 & 201 & 242 \\
\hline 210 & 199 & 235 & 259 \\
\hline 254 & 279 & 222 & 240 \\
\hline 212 & 233 & $\overline{\mathbf{x}}=212.1$ & $\bar{x}=226.4$ \\
\hline 232 & 216 & $S=18.9$ & $\mathrm{~S}=22.0$ \\
\hline 245 & 230 & & \\
\hline 290 & 264 & & \\
\hline 248 & 252 & & \\
\hline 215 & 231 & & \\
\hline 230 & 235 & & \\
\hline $\bar{x}=224.5$ & $\bar{x}=233.7$ & & \\
\hline$S=27.5$ & $S=22.6$ & & \\
\hline
\end{tabular}

value is already decreased in the 12th week from $26.7 \mathrm{ml} / \mathrm{min} / \mathrm{mmHg}$ to $24.6 \mathrm{ml}(2 \mathrm{p}<0.01)$ (Tab. IV).

g) Oxygen consumption: This is increased in both groups already in the 12th week of pregnancy (2p for both groups $<0.05$ ) and is the same in both groups (Tab. V).

\section{Discussion}

It is noteworthy that the diffusion capacity is significantly decreased in the 8 dyspneic women in the 12 th week of gestation $(2 p<0.01)$ but remains unchanged in the control group. In the 12th week of pregnancy the difference between the two groups is significant for $2 p$ $<0.05$. As the diffusion capacity decreases in the dyspneic group hyperventilation sets in. Outside of pregnancy the minute volume of these women was 8.41 and this rose to 10.11 in the 12th week of pregnancy, i. e. a rise of $20 \%$. In the control group the rise was from 7.9 to $8.3 \mathrm{l} / \mathrm{min}$, i. e. only $5 \%$. The difference between the two groups in the 12th week of pregnancy is significant for $2 p<0.01$. The increased minute volume in the dyspneic group is due to a larger increase in the tidal volume. The respiratory rate is the same in both groups (15 min). Hence the rise in minute volume is solely due to an increase in the tidal volume. In the control group the tidal volume increases by $55 \mathrm{ml}$ in the 12th week while in the dyspneic group the increase is $101 \mathrm{ml}$, i. e. $10 \%$ in the control and $19 \%$ in the dyspneic group. Although oxygen consumption is increased already in the 12th week of gestation in both groups, there is no difference between them, inspite of the significantly higher minute volume in the dyspneic women. In other words in early pregnancy dyspneic women do not show a greater rise in oxygen consumption although their minute volume is raised. Hence these women must ventilate more in order to achieve the same rate of oxygen consumption as found in the controls. The extra work required for this increased ventilation is felt as shortness of breath. These findings may be explained by an increased impairment of diffusion in the dyspneic group. Dyspnea appears at a time when the diffusion capacity is significantly decreased. In control pregnant women oxygen consumption and hence ventilation and respiratory effort are also raised. This increased effort is felt as dyspnea only in those women, in whom the impairment of diffusion is strong enough to make increased hyperventilation necessary. In normal women the diffusion capacity also decreases significantly as pregnancy progresses and for them it is also 
possible to make this decrease responsible for the further increase in hyperventilation [4]. Not only the necessary increase in oxygen consumption leads to increased ventilation. The oxygen consumption does not rise at the same rate as the minute volume. WULF [11] has calculated a partial pressure of oxygen of 105 to 110 Torr for the degree of hyperventilation at the end of pregnancy. The actual figure however, was only 92 Torr. Bartels et al. [2] and Rooth [9] and also VASIKA [10] found no significant difference in the $\mathrm{pO}_{2}$ between pregnant and non pregnant women. The arterial $\mathrm{pCO}_{2}$ decreases significantly during pregnancy. Since $\mathrm{CO}_{2}$ diffuses much more readily than $\mathrm{O}_{2}$ it decreases during hyperventilation. HeIdENREICH et al. [5] found an increased flow resistance after the 25 th week of pregnancy. This is contradicted by the finding that often dyspnea occurs already in weeks 10 to 12 , i. e. at a time when according to this author [5] the flow resistance has notyet altered.

\section{Summary}

In $20 \%$ of pregnancies, dyspnea at rest occurs as early as the 12 th week of gestation, and $60 \%$ of women in pregnancy complain of dyspnea following moderate exertion. In order to clarify this dyspnea, the pulmonary function studies of 23 women were examined in the 12th, 24th, 32nd and 36th week of gestation and also at 12 weeks post partum. Eight patients complained of dyspnea at rest as early as the 10th and 12th week of gestation. The changes of ventilation were determined by measurement of tidal, respiratory rate and minute ventilation. $\mathrm{O}_{2}$-uptake, working against total pulmonary resistance, compliance and diffusion capacity were the other parameters measured in this study. The oxygen uptake was reduced to standard condition and dry (STPD). By means of an esophageal ballon technique compliance and working against total pulmonary resistance were investigated. Diffusing capacity was determined by the breath-holding technique. There was a significant decrease of the diffusion capacity in the 12 th week in all 8 dyspneic women, although no changes
In addition we found no significant changes in compliance in our women, nor did we find a change in the work against viscous resistance. This respiratory resistance consists of tissue resistance and respiratory pathways resistance, with $20 \%$ due to the tissues and $80 \%$ to the pathways. An increase in the resistance of the latter would thus have to lead to increased respiratory work against a viscous resistance and this was found not to be the case.

We believe, on the basis of our data, that dyspnea in early pregnancy is due to a fall in the diffusion capacity of the lungs. This may be explained by a rise in the diffusion distance. There may be a causal relationship to the increased level of estrogen in pregnant women. This is discussed elsewhere [6]. It should be mentioned, however, that an intravenous injection of estriol given experimentally, may cause a fall in diffusion capacity and a simultaneous rise in ventilation.

were observed in the control group (Tab. IV). The fall of diffusion capacity during pregnancy is explained by an estrogen effect on capillary and alveolar walls and the interstitial tissue of the lung. Minute ventilation in the dyspnoic group increased by $20 \%$ in the 12 th week, while only by $5 \%$ in the controls (Tàb. II). The increase in minute ventilation is implemented primarily by an increase in tidal volume. No change of respiratory rate is noticed. Inspite of the significant increase of minute ventilation in dyspneic women, there is no significant difference in the $\mathbf{O}_{2}$-uptake as rompared to the controls (Tab. V). No differences of compliance and working against total pulmonary resistance are measured (Tab. II and III). These data indicate that women with dyspnea in early pregnancy have to compensate for the diffusion efficiency by increased ventilation, in order to reach an $\mathrm{O}_{2}$-uptake comparable to the normal control group. This greater amount of energy involved in breathing is designated as dyspnea by the pregnant women.

Keywords: Diffusion capacity, dyspnea, pregnancy, pulmonary functions.

\section{Zusammenfassung}

Untersuchungen zur Frage der Schwangerendyspnoe Bei $20 \%$ der Schwangeren tritt eine Dyspnoe in Ruhe schon in der 12. Schwangerschaftswoche auf. $60 \%$ der Schwangeren geben eine Kurzluftigkeit bei geringerer körperlicher Belastung an. Um die Ursachen dieser Dyspnoe zu klären, wurden 23 Frauen in der 12., 24., 32. und 36. Schwangerschaftswoche sowie 12 Wochen nach der Entbindung auf ihre Lungenfunktion hin untersucht.
8 Frauen aus diesem Kollektiv gaben eine .Ruhedyspnoe bereits in der 10.-12. Schwangerschaftswoche an. Um die Veränderungen der Ventilation zu erfassen, wurden Atemzugvolumen, Atemfrequenz und Atemminutenvolumen mit einem Spirometer gemessen. Weiterhin wurden die $\mathrm{O}_{2}$-Aufnahme, die Compliance, die Atemarbeit gegen visköse Widerstände und die Diffusionskapazität untersucht. Die Werte über die Messung der Sauerstoffaufnahme 
wurden auf Standardbedingungen bezogen (STPD). Compliance und die Atemarbeit gegen visköse Widerstände wurden mit Hilfe einer Oesophagussonde registriert und errechnet. Dic Diffusionskapazität wurde durch Messung der CO-Diffusion mit Atemanhaltetechnik bestimmt. Bei den 8 dyspnoischen Frauen nimmt die Diffusionskapazität zur 12. Schwangerschaftswoche signifikant ab, während sie bei den Frauen der Kontrollgruppe gleich bleibt (s. Tab. IV). Die Abnahme der Diffusionskapazität wird durch einen Östrogeneffekt auf Kapillar- und Alveolarwand sowie das interstitielle Gewebe der Lunge mit Einlagerung von sauren Mucopolysacchariden erklärt. Das Atemminutenvolumen steigt bei den Frauen mit Dyspnoe in der 12 . Woche um $20 \%$ an, in der Kontrollgruppe nur um 5\% (s. Tab. II). Die Zunahme des Atem- minutenvolumens ist ausschließlich durch eine Steigerung des Atemzugvolumens bedingt. Die Atemfrequenz ändert sich nicht. Compliance und die Atemarbeit gegen visköse Widerstände bleiben unverändert (s. Tab. II und III). Trotz dieser signifikant stärkeren Zunahme des Atemminutenvolumens bei den Frauen mit Dyspnoe, kommt es zu keiner signifikant stärkeren Zunahme der $\mathrm{O}_{2}$-Aufnahme gegenüber den Frauen ohne Dyspnoe. Das bedeutet, daß die Frauen mit einer Dyspnoe in der Frühschwangerschaft mehr ventilieren müssen, um bei der bestehenden Diffusionsstörung die gleiche Sauerstoffaufnahme zu erreichen wie die Schwangeren ohne Dysspnoe. Die mit dieser stärkeren Ventilation erhöhte Atemarbeit wird von den Schwangeren als Dyspnoe empfunden.

\section{Schlüsselwörter: Diffusionskapazität, Dyspnoe, Lungenfunktion, Schwangerschaft.}

\section{Résumé}

\section{Examples relatifs à la dyspnée de grossesse}

Chez $20 \%$ des femmes enceintes on observe une dyspnée au repos dès la 12ème semaine de grossesse. $60 \%$ des femmes enceintes enregistrent une gêne respiratoire au moindre effort physique. Afin de préciser les causes de cette dyspnée nous avons examiné la fonction pulmonaire de 23 femmes au cours des 12ème, 24ème, 32ème et 36ème semaines de grossesse ainsi que 12 semaines après l'accouchement. Parmi ce groupe, 8 femmes ont révélé une dyspnée de repos dès la 10-12ème semaine de grossesse. Pour enregistrer les changements de ventilation on a mesuré le volume du souffle, la fréquence respiratoire et le volume respiratoire par minute à l'aide d'un spiromètre. Ont été également examinés l'absorption d'oxygène, la compliance, le travail respiratoire contre les résistances visqueuses et la capacité de diffsuion. Les valeurs sur la mesure de l'absorption d'oxygène ont été rapportées à des conditions standard (STPD). La compliance et le travail respiratoire contre les résistances visqueuses ont été entegistrés et calculés à l'aide d'une sonde de l'oesophage. La capacité de diffusion a été déterminée par la mesure de la diffusion $\mathrm{CO}$ avec la technique de retention du souffle.

Chez les 8 femmes dyspnoiques, la capacité de diffusion à la 12ème semaine de grossesse baisse de façon significative tandis qu'elle reste stationnaire chez les femmes du groupe de contrôle (cf. Tab. IV). La baisse de la capacité de diffusion s'explique par un effet d'oestrogène sur la paroi capillaire et alvéolaire ainsi que le tissu interstitiel du poumon avec le dépôt de mucopolysaccharides acides. La capacité pulmonaire monte de $20 \%$ chez les femmes dyspnoiques dans la 12ème semaine de grossesse et de $5 \%$ seulement chez le groupe de contrôle (cf. Tab. II). La hausse de la capacité pulmonaire est conditionnée exclusivement par une augmentation du volume de souffle. $\mathrm{La}$ fréquence respiratoire ne change pas. $\mathrm{La}$ compliance et le travail respiratoire contre les résistances visqueuses restent inchangés (cf. Tabs. II et III). Malgré cette hausse nettement plus accentuée de la capacité pulmonaire chez les femmes dyspnoiques, on n'observe aucune augmentation significativement plus forte d'absorption de $\mathrm{O}_{2}$ par rapport aux femmes sans dyspnée. Cela signifie que les femmes dyspnoiques en début de grossesse doivent davantage ventiler pour atteindre, en présence du trouble persistant de diffusion, la même absorption de $\mathrm{O}_{2}$ que les femmes enceintes non dyspnoiques. L'augmentation du travail respiratoire consécutive à cette ventilation plus forte est ressentie comme une dyspnée par les femmes enceintes.

Mots-clés: Capacité de diffusion, dyspnée, fonction pulmonaire, grossesse.

\section{Bibliography}

[1] Comroe, J. H., R. E. Forster, A. B. DuBors, W. A. Briscoe, E. Carlsen: Die Lunge. Klinische Physiologie und Funktionsprüfungen. Schattauer, Stuttgart 1968

[2] Bartels, H., E. Büchert, C. W. Hertz, G. RodeWALD, M. SCHWAB: Lungenfunktionsprüfungen, Methoden und Beispiele klinischer Anwendung. Springer, Berlin-Göttingen-Heidelberg 1959

[3] Cugell, D. W., R. Frank, E. A. Gaenster, T. L. BADGer: Pulmonary function in pregnancy. Amer. Rev. Tuberc. 67 (1953) 568
[4] Forster, R. E., W. S. Fowler, D. V. Bates, V. van LINGEN: The absorption of carbon monoxide by the lungs during breath-holding. J. clin. Invest. 33 (1954) 1135

[5] Heidenreich, J., B. LüKen, V. Schulz, K. H. SCHNABEL, L. BECK: Die Ventilation bei Schwangeren mit Dyspnoe. Vortrag Dtsch. Ges. f. Gyn., 39. Tg. Wiesbaden 1972

[6] LehmanN, V.: Veränderungen der Lungendiffusionskapazität als mögliche Ursache der Hyperventilation in der Schwangerschaft (in preparation) 
[7] LehmanN, V., H. Fabel: Lungenfunktionsuntersuchungen bei Schwangeren. Z. Geburtsh. u. Perinat. (in press)

[8] Lucius, H., H. Gahlenbeck, H. O. Kleine, $H$. FABEL, H. BARTELS: Respiratory functions, buffer system, and electrolyte concentrations of blood during human pregnancy. Resp. Physiol. 9 (1970) 311

[9] Rooth, G., S. SJöstedt: The placental transfer of gases and fixed acids. Arch. dis. Childh. 37 (1962) 366
[10] Vasicka, A., E. J. Qüllligan, R. AzNar, P. J. LIPSITZ, B. M. BLOOR: Oxygen tension in maternal and fetal blood, amniotit fluid, and cerebrospinal fluid of the mother and the baby. Amer. J. Obstet. Gynec. 79 (1960) 1041

[11] WULF, H.: A comparative study of actuel blood gases and acid-base metabolism in maternal and fetal blood during parturition. Int. Symp., Prague 1966, Excerpta Med. Monograph.

Priv.-Doz. Dr. med. V. Lehmann Universitäts-Frauenklinik und Hebammenschule 8700 Würzburg

Josef-Schneider-Str. 4 